\title{
Typology of organic residues attracting flies and their utilization in the agricultural sector in southern Benin
}

\author{
Adin Yéton BLOUKOUNON-GOUBALAN ${ }^{1 *}$, Aliou SAIDOU ${ }^{1}$, Victor CLOTTEY ${ }^{2}$, \\ Christophe Achille Armand Mahussi CHRYSOSTOME ${ }^{3}$, Marc KENIS ${ }^{4}$ and \\ Guy Apollinaire MENSAH ${ }^{5}$ \\ ${ }^{1}$ Research Unit of Integrated Management of Soil and Crops, Laboratory of Soil Sciences, \\ Faculty of Agronomics Sciences, University of Abomey-Calavi, 01 BP 526 RP Cotonou, Benin. \\ ${ }^{2}$ CABI, CSIR Campus, No.6 Agostino Neto Road, Airport Residential Area, \\ PO Box CT 8630, Cantonments, Ghana. \\ ${ }^{3}$ Laboratory of Avicultural and Zoo-Economic Research, Faculty of Agronomics Sciences, \\ University of Abomey-Calavi, 01 BP 526 RP Cotonou, Benin. \\ ${ }^{4}$ CABI, Rue des Grillons 1, 2800 Delémont, Switzerland. \\ ${ }^{5}$ Laboratory of Zootechnology, Veterinary and Fisheries Research, Center of Agronomic Research of \\ Agonkanmey (CRA-Agonkanmey), National Institute of Agricultural Research, \\ 01 BP 884 RP, Cotonou 01, Benin. \\ *Corresponding authors; E-mail: adinbloukounon@gmail.com ; Tel: 0022996152967
}

\section{ACKNOWLEDGEMENTS}

This study was made in the framework of the project, IFWA - Sustainable use of insects to improve livestock production and food security in smallholder farms in West Africa, funded by the Swiss Agency for Development and Cooperation and the Swiss National Science Foundation, in the framework of the Swiss Programme for Research on Global Issues for Development (R4D). MK was partly funded through the CABI Development Fund (supported by contributions from the Australian Centre for International Agricultural Research, the UK's Department for International Development, and others).

\begin{abstract}
The use of fly larvae as protein source for poultry and agent of biodegradation of organic substrates such as manure proves to be a promising and innovative technology for resource poor farmers. The study aimed at categorizing the organic substrates regarding their capacity to attract flies and to produce fly larvae, and at discussing their utilization in the agricultural domain in southern Benin. A total of 390 farmers were surveyed from October to November 2015 in the six departments (Atlantique, Ouémé, Plateau, Mono, Couffo and Zou) of southern Benin using an open-ended questionnaire. Most of the farmers had limited knowledge on the use of fly larvae to feed poultry. Some of them were not aware of the role of fly larvae in the degradation of the organic substrates. Three utilizations of these organic substrates were mentioned by the farmers: organic fertilizer, fly larvae production, and food for poultry. Animals' intestines, carcasses, poultry manure, pig manure were mentioned as animal residues attracting flies and potentially suitable for fly larvae production. Suitable plant residues for fly larvae production included agro-artisanal by-products such as soybean bran, corn bran and sorghum bran; brewery malt, rotten papaya fruits, mango rind and rotten banana fruits. The study suggests that these different types of substrate should be assessed for their suitability in fly larvae production and that the quality of residues obtained from the degradation by the fly larvae should be evaluated in the perspective of soil fertility replenishment.
\end{abstract}

(C) 2017 International Formulae Group. All rights reserved.

Keywords: organic residue, fly larvae, organic manure, soil fertility, farmer perception. 


\section{INTRODUCTION}

Soil fertility is currently at the center of the debates on sustainability of production systems in Sub-Saharan Africa. The fertility of the productive soils of this region is declining (Hodomihou et al., 2011; Saïdou et al., 2012; Sossa-Vihotogbé et al., 2013). This phenomenon is accelerated by inadequate practices such as exclusive use of inorganic fertilizers, burning and export of crop residues without proper restitution measures (Saïdou et al., 2008). In Benin, this situation is particularly alarming in the southern part of the country where population density is high (Saïdou et al., 2003). Soils of this region are acrisols and locally known as "Terre de barre". They are characterized by very low cation exchange capacity (Igué et al., 2013) derived from a stable low organic matter content (Saidou et al., 2003; Igué, 2009; Bloukounon et al., 2015).

To achieve sustainable agricultural production on these soils, there is a need to intensify crop-livestock integrated cropping systems in which crops will benefit from the nutrients in the animal manure, which in turn is fed with crop products. This intensive farming system has a remarkable advantage as it optimizes the use of arable land area, which tends to decline due to the demographic pressure. Also, the use of organic manure was reported to improve crops production (Amadji et al., 2009; Bloukounon et al., 2015). However, an organic manure of poor quality (i.e. immature and unstable) represents a loss for the farmers because they do not increase yields and, instead, increase the risk of phytotoxicity (Cambardella et al., 2003). Composting organic manure usually increases its quality. But in the perspective of croplivestock integration, scientific research is increasingly turning towards less constraining systems that offer direct benefits for both agriculture and livestock.

The use of fly larvae to improve the biodegradation process of organic wastes is increasingly explored since larvae also provide a source of protein for poultry (Bouafou, 2007; Kenis et al., 2014) and residues can be used as compost for soil fertility replenishment (Diener et al., 2015; Koné et al., 2017). The main fly species used for that purpose are the house fly (Musca domestica) and the black soldier fly (Hermetia illucens) (Pastor et al., 2015). This technology is not well known in the developing countries even if there are neglected and locally available resources that can be used by farmers to produce larvae and high-value organic compost. Fly larvae easily degrade organic material of different origins such as domestic, market and agri-food waste, poultry, pig and cow manures and even human excreta (Diener et al., 2011; Banks et al., 2014). Fly larvae activity induces a decomposition and humification of dissolved organic matter (Wang et al., 2016), an increased loss of water and ammonia, and growth of aerobic microorganisms (Čičková et al., 2015) generating a more stable bioproduct for soil restoration than the original substrate (Wang et al., 2016).

In Benin, research activities in this area are just starting. Djissou et al. (2015) evaluated the production of fly larvae in a few substrates. Pomalegni et al. (2016) presented farmer's perception on the use of fly larvae to feed poultry and types of substrates that produced larvae. Nevertheless, farmers typology of substrates regarding their capacity to produce fly larvae has not yet be addressed. Our study aimed at addressing these issues in order to improve the knowledge in the availability and the different use of the organic substrates that can be used for fly larvae production on farm. Specifically, it aimed at i) identifying the organic substrates attracting flies and those that are already used by farmers to produce fly larvae; ii) at identifying the different forms of utilization of these substrates by farmers ; iii) finally at making a typology of these organic substrates regarding their capacity to produce fly larvae. 


\section{MATERIALS AND METHODS Study areas}

The survey was carried out from October to November 2015 in the Atlantic, Ouémé, Plateau, Mono, Couffo and Zou departments located in southern Benin (Figure 1). The climate of the study area is subequatorial with two dry and two rainy seasons. The region is characterized by acrisols from the continental terminal (USDA, 1998). These soils are known to be poor in organic matter (Saïdou et al., 2003) and require organic amendment for sustainable crop production.

\section{Sampling method and type of data collected}

The sample size was obtained by using the normal approximate of the binomial distribution proposed by Dagnelie (1998).

$N=\frac{U_{1-\frac{\alpha}{2} \times p(1-p)}}{d^{2}}$

Where $U_{1-\alpha / 2}$ is the normal random variable value with probability of $1-\alpha / 2, \alpha$ is the error risk. For example if $\alpha=5 \%$, the probability of $1-\alpha / 2=0.975$ and $U_{1-\alpha / 2}=1.96$.

$p$ is the proportion of farmers involved in poultry breeding in the study area and $d$ the error margin, which was fixed at $5 \%$ in this study. Considering that using fly larvae as protein source would be most useful to poultry farmers who, in the study area, are known to face difficulties in providing protein-rich poultry feed, we focused our survey on this category of farmer. We hypothesized that the technology of fly larvae production may be of high interest to them. Therefore, based on the $p$ values and the statistics of poultry farming collected from the Direction de l'Elevage (2005), a total of 390 farmers who include poultry in their activities were selected.

The number of farmers per department was determined according to the relative proportion of poultry farmers in the departments (FAO, 2015). Thus, 55, 47, 47, 35, 36 and 170 farmers were selected respectively in the Atlantic, Ouémé, Plateau, Mono, Couffo and Zou departments for the interview. In each department, the districts surveyed were selected based on the importance of poultry farming. Within a district, people to be interviewed were selected by simple random sampling. Table 1 presents the number of farmers interviewed in each district.

The interviews were conducted using an open end questionnaire allowing the respondents to express their point of view to a question asked. Enumerators, mostly University students originating from the region were selected to carry out the survey. The farmers were asked to: list the organic substrates produced by the agricultural sector and are available in the rural areas; list the organic substrates attracting flies; state the traditional use of the listed substrates; provide information on farmers' indigenous knowledge on the practice of fly larvae; and rank the organic substrates regarding their performance in housefly production. This ranking was made by the farmers who have already produced fly larvae.

\section{Data analysis}

The Epidata software was used to record the data collected during the interviews. Then SPSS 16.0was used to determine the relative frequencies of responses given by the farmers on the practice of fly larvae production. For each substrate listed, the frequency of citation was calculated for each category as follows:

Frequency of citation $=$

$\frac{\text { Number of citations of the substrate }}{\text { Number of farmers }} \times 100$

The factorial correspondence analyses were performed with R. 3.0.2 software linking the substrate identified with their utilization. For the ranking process, the rank mentioned by the absolute majority of people was considered. 


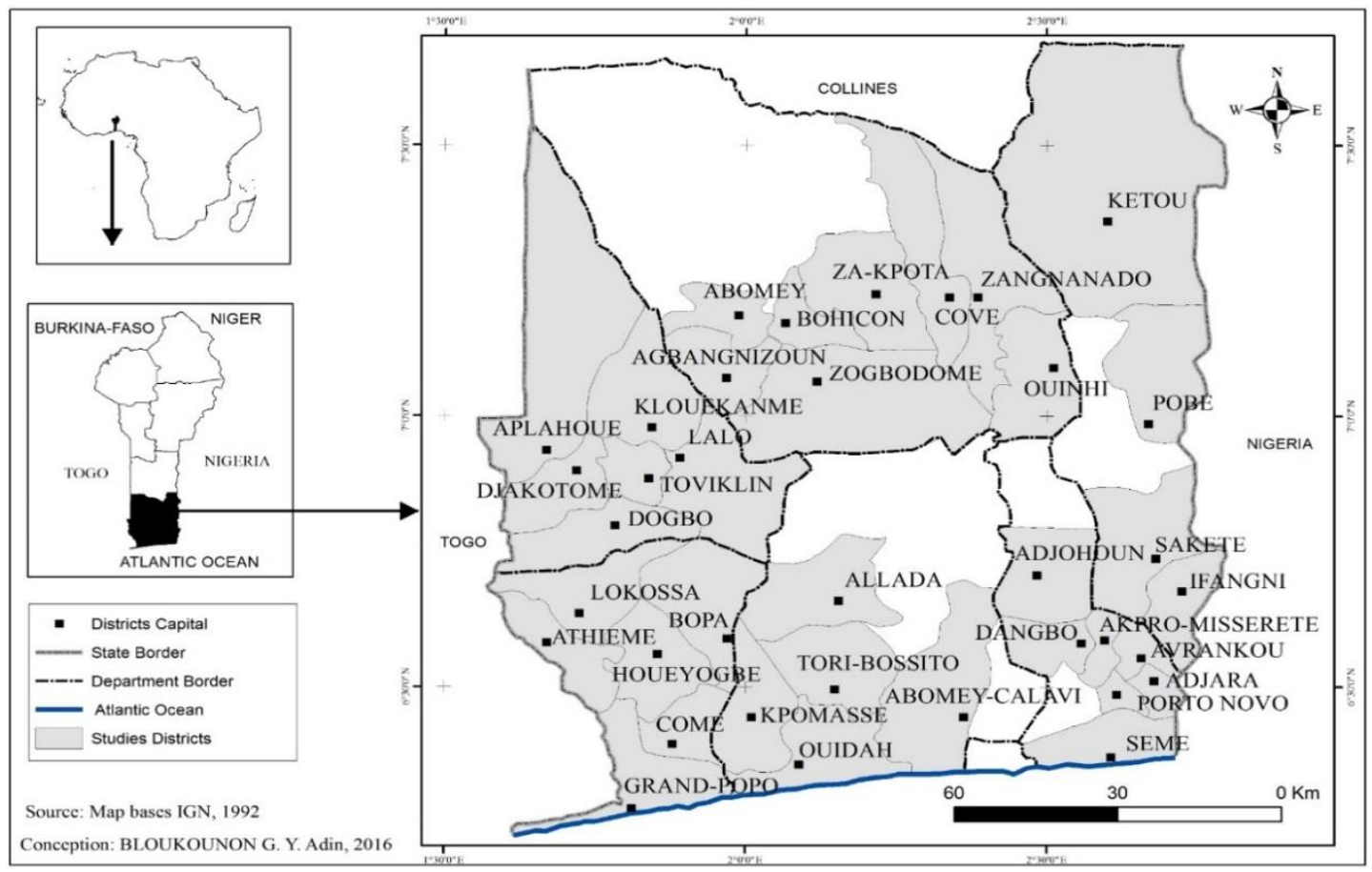

Figure 1: Map of the study areas.

Table 1: Number of farmers interviewed in each district.

\begin{tabular}{lcc}
\hline Departments & Districts & Number of farmers surveyed \\
\hline Atlantic & Abomey-Calavi & 19 \\
& Allada & 18 \\
& Ouidah & 18 \\
\hline Couffo & Aplahoué & 11 \\
& Klouékanmey & 10 \\
& Lalo & 7 \\
& Djakotomey & 8 \\
\hline Mono & Athiémé & 12 \\
& Bopa & 12 \\
& Houéogbé & 11 \\
\hline Ouémé & Adjarra & 11 \\
& Adjohoun & 11 \\
& Dangbo & 12 \\
& Missérété & 13 \\
\hline Plateau & Ifangni & 16 \\
& Kétou & 16 \\
& Pobé & 15 \\
\hline Zou & Zagnanado & 33 \\
& Covè & 32 \\
& Ouinhi & 31 \\
& Zogbodomey & 26 \\
& Agbangnizoun & 24 \\
& Zakpota & 24 \\
\hline
\end{tabular}




\section{RESULTS}

\section{Inventory of the organic substrates}

Several substrates used and/or produced by the agricultural sector were listed by the respondents. Table 2 shows the organic substrates from animal and plant origins cited by the farmers. The farmers cited more organic substrates from animal origin $(75.38 \%)$ than from plants $(7.43 \%)$. Animal carcass followed by sheep manure, cow dung, animal intestines, poultry manure and pig manure were the animal substrates most cited by the farmers. Rabbits manure, rotten or dried fish, rotten meat, human waste, rabbit skin and blood were mentioned by a few farmers.

With regards to the substrate from plant origin, the agro-processing by-products (corn bran, soybean bran, sorghum bran) followed by brewery waste and kitchen waste were the most mentioned. Mango rind, rotten papaya and rotten banana were also cited as substrates. Maize flour, cassava peel, mustard waste, crop residues, fodder and banana peels were all reported by less than $1 \%$ of the farmers.

The farmers' perception on the suitability of these substrates to attract flies is presented in Table 3. About $65 \%$ of the farmers who mentioned animal's intestine as substrates indicated it as the best fly attractant, followed by animals' carcass mentioned by $81 \%$ of the farmers who cited it. Pig and poultry manures were ranked respectively third and fourth by most farmers. Cow dung, sheep and rabbit manures were not well ranked suggesting their weak performance in attracting flies. Among plant substrates, mango rind and rotten banana were ranked first and second respectively as fly attractants. Agro-processing by-products such as soybean bran, corn bran and sorghum bran were ranked third in terms of fly attraction whereas, brewery waste, rotten papaya and kitchen waste were less attractive. In general, according to the farmers' perception, animalbased residues attract much more flies compared to plant-based ones.

\section{Utilization by farmers of the organic substrates}

The main forms of utilization of the organic substrates by the farmers are presented in Figure 2. The organic substrates were mostly used as soil amendment, food for poultry and, to a lower extent, for fly larvae production. Among these substrates, according to the farmers' perception, only cow dung, pig manure, sheep manure, rabbit manure, poultry manure, and abbatoir waste are suitable for soil amendment. In general, cow dung, pig manure, sheep manure and rabbit manure were used for soil fertility restoration (Figure 2). Animals intestine and poultry manure were used for fly larvae production. The agro-processing by-products and brewery waste were used to feed poultry. Rotten papaya and kitchen waste were thrown away and eaten by scavenging poultry.

\section{Farmers' perception on the performance of the organic substrates for fly larvae production}

Sixteen farmers (4\%) said that they presently produce and use fly larvae to feed their poultry. These were asked to rank the substrates by their performance in producing fly larvae. The ranking is presented separately for substrates from animal and plant origins (Table 4). Animals' intestine and poultry manure, and agro-processing by-products and brewery waste were classified as first and second in the two groups. 
Table 2: Farmers perception on the type of substrates used in or produced by the agricultural sector with the corresponding frequencies of citation.

\begin{tabular}{lccc}
\hline $\begin{array}{l}\text { Substrate from animal } \\
\text { origin }\end{array}$ & $\begin{array}{c}\text { Frequency of } \\
\text { citation }(\boldsymbol{\%})\end{array}$ & Substrate from plant origin & $\begin{array}{c}\text { Frequency of } \\
\text { citation } \mathbf{( \% )}\end{array}$ \\
\hline Animal carcass & 74.36 & Agro-processing by-products & 5.38 \\
Sheep manure & 74.22 & Brewery waste & 4.62 \\
Cow dung & 74.19 & Kitchen waste & 2.82 \\
Animal intestine & 66.67 & Mango rind & 2.82 \\
Poultry manure & 63.61 & Sorghum beer & 2.82 \\
Pig manure & 60.54 & Rotten papaya & 1.79 \\
Rabbit manure & 34.42 & Rotten banana & 1.79 \\
Rabbit skin & 0.34 & Maize flour & 0.51 \\
Rotten fish & 1.36 & Cassava peel & 0.51 \\
Dried fish & 0.34 & Mustard waste & 0.51 \\
Blood & 0.34 & Crop residues & 0.26 \\
Rotten meat & 1.02 & Fodder & 0.26 \\
Humans excrements & 0.34 & Banana peels & 0.26 \\
Abbatoir waste & 1.02 & & \\
\hline Total of farmers & 75.38 & & 7.43 \\
\hline
\end{tabular}

Table 3: Ranking the organic substrates based on their potential to attract flies.

\begin{tabular}{lccc}
\hline Substrate from animal origin & $\begin{array}{c}\text { Rank }\left(^{*}\right) \\
\mathbf{n = 2 9 4}\end{array}$ & Substrate from plant origin & $\begin{array}{c}\text { Rank }\left(^{*}\right) \\
\mathbf{n = 2 9}\end{array}$ \\
\hline Animal intestine & $1^{\text {st }}(65)$ & Mango rind & $1^{\text {st }}(65)$ \\
Animals carcass & $2^{\text {nd }}(81)$ & Rotten banana & $2^{\text {nd }}(66)$ \\
Pig manure & $3^{\text {rd }}(60)$ & Agro-processing by-products & $3^{\text {rd }}(70)$ \\
Poultry manure & $4^{\text {th }}(60)$ & Brewery waste & $4^{\text {th }}(60)$ \\
Cow dung & $5^{\text {th }}(70)$ & Rotten papaya & $5^{\text {th }}(65)$ \\
Sheep manure & $6^{\text {th }}(82)$ & Kitchen waste & $6^{\text {th }}(57)$ \\
Rabbit manure & $7^{\text {th }}(57)$ & Maize flour & - \\
Rabbit skin & - & Cassava peel & - \\
Rotten fish & - & Mustard waste & - \\
Dried fish & - & Wet crop residues & - \\
Blood & - & Wet fodder & - \\
Rotten meat & - & Banana peels & - \\
Humans excrements & - & Sorghum beer & - \\
Butcher's waste & - & & \\
\hline
\end{tabular}

*: Percentage of farmers who ranked the substrate are in parenthesis.

- : Not ranked by the farmers 

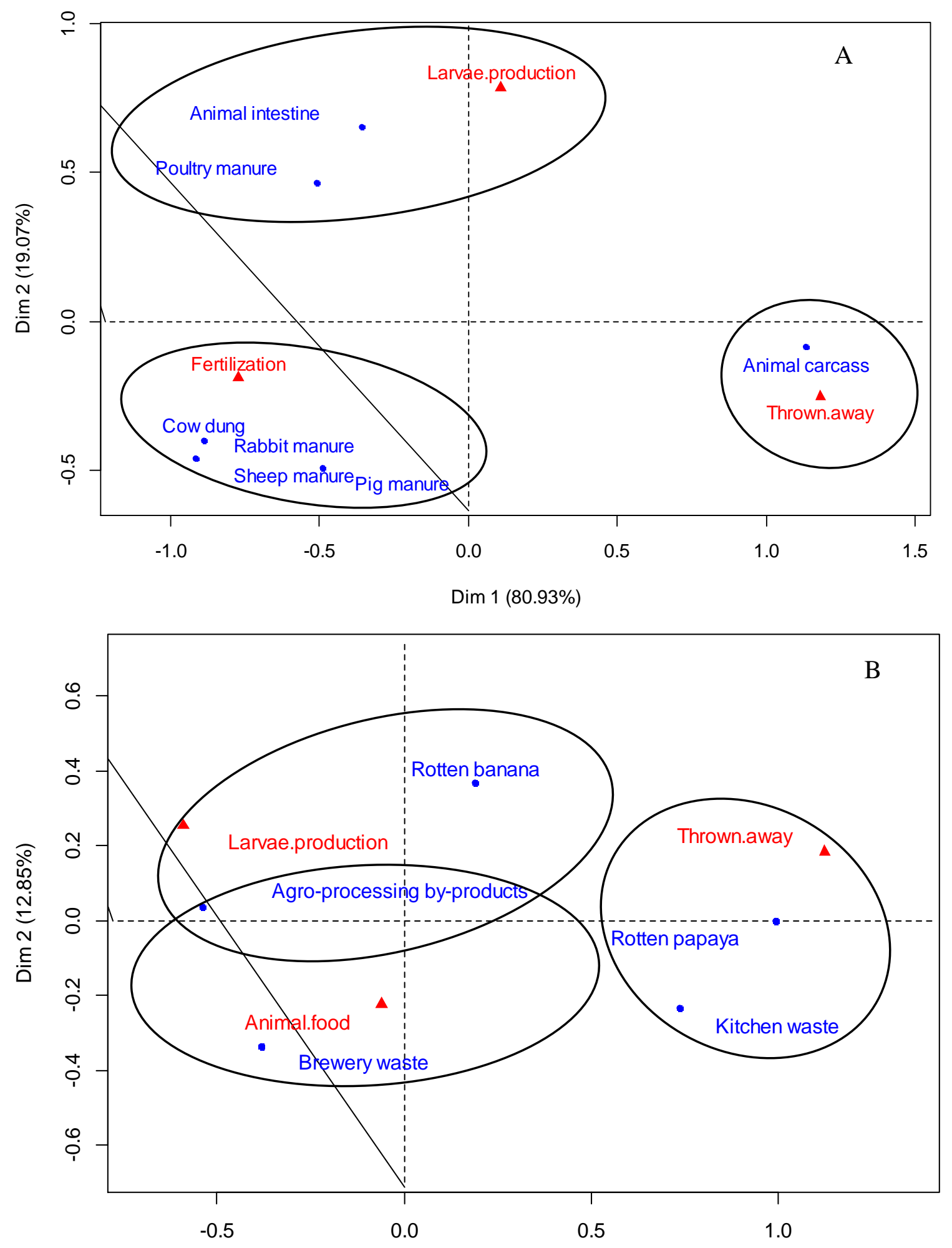

$\operatorname{Dim} 1(87.15 \%)$

Figure 2: Factorial correspondences analyses of farmers' perception on the different uses of substrates of animal (A) and plant origin (B). 
Table 4: Farmers' perception of the performance of the organic substrates in fly larvae production.

\begin{tabular}{lccc}
\hline Animals substrates & $\begin{array}{c}\text { Rank }(*) \\
(\mathbf{n = 1 6})\end{array}$ & Plants substrates & $\begin{array}{c}\text { Rank }\left(^{*}\right) \\
(\mathbf{n}=\mathbf{1 6})\end{array}$ \\
\hline Animals intestine & $1^{\text {st }}(85)$ & Agro-processing by-products & $1^{\text {st }}(80)$ \\
Poultry manure & $2^{\text {nd }}(88)$ & Brewery waste & $2^{\text {nd }}(81)$ \\
Pig manure & $3^{\text {rd }}(88)$ & Rotten papaya & $3^{\text {rd }}(55)$ \\
Animals carcass & $4^{\text {th }}(89)$ & Mango rind & $4^{\text {th }}(60)$ \\
Cow dung & $5^{\text {th }}(89)$ & Rotten banana & $5^{\text {th }}(63)$ \\
Sheep manure & $6^{\text {th }}(53)$ & & \\
\hline
\end{tabular}

*: Numbers in parenthesis are the percentage of farmers who had used the substrate in larvae production and ranked, $\mathrm{n}=16$.

\section{DISCUSSION}

\section{Identification of organic substrate attracting fly larvae}

The present study reveals that organic substrates from animals were more often mentioned by the farmers than that from plant residues. Such situation is due to the fact that animals are reared in all rural households in Benin and their substrates (carcass, intestine or manure) are more available than substrates of plant origin.

Among substrates from animal origin, intestines and carcasses are reported to be the most suitable to attract flies, certainly due to the putrefaction odor that characterizes them. Pig manure was reported to attract more flies than others manures. This is probably due to the fermentation odor which is a significant attractant for female house flies (Tang et al., 2016). This observation made by the farmers corroborates the observation of Bouafou (2011) who showed that pig manure is among the most suitable substrates for fly larvae production. Cow, rabbit and sheep manures were cited as less attractive for flies. These substrates have a lower ammonia content due to the quality of feed eaten by the animals and release less putrefying odors.

Mango rind was ranked as the best fly attractant among substrates of plant origin, probably because of its high sugar content. However, not all attractive substrates can produce fly larvae. Egg hatching and larval development require specific conditions of moisture, texture and temperature (Myers et al., 2008; Sanchez-Arroyo and Capinera, 2008; Sheppard and Newton, 2011). That may explain why the ranking provided by the farmers regarding fly attraction differs from that for fly production.

\section{Utilization of the substrates degraded by the fly larvae}

Cow, pig, sheep and rabbit manures are extensively used as organic manure contrary to poultry manure. This is due to the fact that poultry, largely dominated by chicken in the region (Karim et al., 2013) is reared in extensive systems where animals are scavenging. This makes the collection of manure for crop production problematic. In contrast, cow, pig, sheep and rabbit are reared in semi extensive systems where the manure can be easily collected and stored for fertilization. The use of poultry manure for fly larvae production has been reported by farmers who reared poultry in semiconfinement. The agro-processing byproducts (corn bran, soybean bran, sorghum bran) were also reported as substrates suitable for fly larvae production, which are often observed when these agro-processing byproducts are stored for their use as animal feed. 


\section{Fly larvae production in the organic substrates}

Only $4 \%$ of the farmers produced fly larvae as a source of protein for poultry. This frequency is rather similar to the $5.73 \%$ observed by Pomalegni et al. (2016) in Benin. In general, the farmers had a good knowledge of the fly larvae although they call it in the local language "worms" i.e. similar to other insect larvae and worms. But most of them did not know that it can be produced and used as a source of protein for poultry. Those using fly larvae are generally traditional poultry farmers whose poultry scavenge (Pomalegni et al., 2016). Several farmers expressed the fact that they frequently observed their poultry foraging for insects, earthworms and other invertebrates as also mentioned by Ayssiwede et al. (2011). Some farmers were reluctant to give fly larvae to their poultry. This reluctance is understandable but not fully justified. Veldkamp et al. (2012) reported that the fly larvae present no direct risk for the poultry, in contrast to adults, but they can accumulate heavy metals if the substrates are contaminated. Thus, for fly larvae production, the substrates should contain no or permissible amounts of heavy metals.

Several substrates of animal and plant origin are used to produce fly larvae. In our study, farmers already producing and using maggots ranked animal intestines first. This is certainly due to the fact that it is highly attractive to adult flies. However, animal intestines are never used alone to produce fly larvae but rather used as attractants with other substrates, in particular poultry and pig manures, which were ranked respectively second and third most efficient substrates. Cow dung and sheep manure were ranked as low value substrates. It is a well-known fact that ruminant manures alone are poor substrates for producing fly larvae because of their low nutritional value and, especially, their low protein content (Mpoame et al., 2004; Koné et al., 2017). However, they can be used in mixture with highly attractive and nutritious substrates such as blood or fish offal (Koné et al., 2017). Agro-processing byproducts were ranked first within plant organic substrates. These are domestic by- products largely available on farm. In a similar survey in Benin, Pomalegni et al. (2017) showed that poultry farmers that produced fly larvae on farm used mainly soybean and maize bran (here included in the category "agro-processing by-products") and pig and chicken manure and animal cadavers.

Perspectives for the valorization of substrate degraded by fly larvae as organic manure

The survey has shown that soil fertility restoration, fly larvae production and animal feed are three ways of utilizing substrates in the study area. Pig, sheep, rabbit and cow manure are mainly used for soil fertility restoration usually after composting to facilitate handling, transportation and management (Bernal et al., 2009). This process has the advantage to improve the $\mathrm{C}: \mathrm{N}$ ratio of the substrates (Larney et al., 2007) which are usually rich in carbon and low in nitrogen. Producing fly larvae with these organic substrates before using them as compost has a double advantage. Fly larvae are an excellent source of protein for poultry (Bouafou, 2007; Hwangbo et al., 2009) but also excellent biodegraders of organic material (Bouafou et al., 2006). The biodegradation of the organic waste by the dipteran larvae is faster than the simple compost process because of the short development cycle of the insects, which varies between 4 to 30 days, depending on the species (Myers et al., 2008). The manure residue becomes noticeably granular and its moisture content goes below $60 \%$, which is suitable for further composting without adding bulking agents (Zhu et al., 2015). The mouthpart of fly larvae, which is of crusher type, allows them to drill, cut and shred residues, which accelerates the decomposition process and plays an important role in nutrient recycling. For example it was demonstrated that black soldier fly larvae easily degrade organic matters of different sources, including domestic waste, poultry manure, pig and cow manure and even human excreta (Diener et al., 2011; Banks et al., 2014). Čičková et al. (2012) demonstrated that house fly larvae reduce $1 \mathrm{~kg}$ of wet manure to range of 0.18 to $0.65 \mathrm{~kg}$. Zhang et al. (2012) and Zhu et al. (2015) also demonstrated that house flies 
reduce significantly the organic carbon and nitrogen in pig manure. Wang et al. (2016) also found a significant decrease of dissolved organic matter concentrations from 192.9 to $77.1 \mathrm{~g} \mathrm{~kg}^{-1}$, an enhancement of the hydrolysis of proteins and lipids, build-up of aromatic substances, and an increase of fulvic and humic substances in pig manure after one week of housefly larvae biodegradation. This generated a more stable bio-product for downstream utilization. Čičková et al. (2012) attributed these changes in the manure during the biodegradation by house fly larvae to the interaction between fly larvae and the microflora (bacteria, yeast and fungi) already present in the manure. Crawling and digestion increased the pore of the material, loss of water, ammonia and favoured the growth of aerobic microorganisms, which are responsible for the decomposition of the resistant compounds. However, the maturity and stability of the final products resulting from fly larvae biodegradation need to be determined in order to evaluate the efficiency of the compost.

\section{Conclusion}

Farmers in southern Benin have limited knowledge on the production of fly larvae on organic substrates. They do know most of substrates from animals and plants origin are able to attract flies. Farmers think that intestines of animals, animals' carcasses, poultry manure, pig manure, agro-processing by-products and brewery waste are suitable for fly larvae production. Further experimentation needs to be done to elucidate that point. The quality of these different types of substrate biodegraded by fly larvae needs to assess with the view of promoting them as soil amendments.

\section{COMPETING INTEREST}

The authors declare that they have no competing interest.

\section{AUTHORS' CONTRIBUTIONS}

AYBG prepared the questionnaire, led the survey and led the writing up of the manuscript. AS, CAAMC Participated in the development of the questionnaire and supervised the research. MK, VC, GAM Participated in the writing up of the manuscript.

\section{ACKNOWLEDGEMENTS}

We warmly thank the interviewers and the farmers who participated in the survey.

\section{REFERENCES}

Amadji GL, Saidou A, Chitou L. 2009. Recycling of organic residues in compost to improve coastal sandy soil properties and cabbage shoot yield in Benin. International Journal of Biological and Chemical Sciences, 3(2): 192-202. DOI: http://dx.doi.org/10.4314/ijbcs.v3i2.4449 7.

Ayssiwede SB, Dieng A, Houinato MRB, Chrysostome CAAM, Issa Y, Hornick JL, Missohou A. 2011. Elevage des poulets traditionnels ou indigènes au Sénégal et en Afrique subsaharienne : Etat des lieux et contraintes. Ann. Méd. Vét., 157 : 103-119.

Banks IJ, Gibson WT, Cameron MM. 2014. Growth rates of black soldier fly larvae fed on fresh human faeces and their implication for improving sanitation. Tropical Medicine and International Health, 19(1): 14-22. DOI: http://dx.doi.org/10.1111/tmi.12228.

Bernal MP, Alburquerque JA, Moral R. 2009. Composting of animal manures and chemical criteria for compost maturity assessment. A review. Bioresource Technology, 100: 5444-5453. DOI: http://dx.doi.org/10.1016/j.biortech.2008 .11.027.

Bloukounon AYG, Saïdou A, Babatoundé S, Balogoun I, Arakogné S, Kassavi E, Adegbidi A. 2015. Effets des fumures NPK et déjections de petits ruminants sur la productivité et la valeur fourragère du maïs et de l'arachide au Sud-Bénin. Annales des Sciences Agronomiques, 19(2): 213-238.

Bouafou KGM, Kouamé KG, Amoikon EK, Offoumou AM. 2006. Potentiels pour la production d'asticots sur des sousproduits en Côte d'Ivoire. Tropicultura, 24: 157-161. 
Bouafou KGM. 2007. Etude de la production d'asticots à partir d'ordures ménagères et de la valeur nutritionnelle de la farine d'asticots séchés (FAS) chez le rat en croissance. Thèse de doctorat: Université de Cocody (Côte d'Ivoire).

Bouafou KGM. 2011. Revue bibliographique sur les asticots et leur emploi dans l'alimentation animale. Journal of Animal and Plant Sciences, 12(2): 15431551. ISSN 2071 - 7024

Cambardella CA, Richard TL, Russell A. 2003. Compost mineralization in soil as a function of composting process conditions. European Journal of Soil Biology, 39: 117-127. DOI: http://dx.doi.org/10.1016/S11645563(03)00027-X.

Čičková H, Newton LG, Lacy CR, Kozánek M. 2015. The use of fly larvae for organic waste treatment. Review. Waste Management, 35: 68-80. DOI: http://dx.doi.org/10.1016/j.wasman.2014 .09.026.

Čičková H, Pastor B, Kozanek M, MartinezSanchez A, Rojo S, Takac P. 2012. Biodegradation of Pig Manure by the Housefly, Musca domestica: A Viable Ecological Strategy for Pig Manure Management. PLoS ONE, 7(3): e32798. DOI: http://dx.doi.org/10.1371/ journal.pone.0032798.

Dagnelie P. 1998. Statistique théorique et appliquée. Tome 2 : Inférences statistiques à une et deux dimensions. De Boeck et Larcier : Paris-Bruxelles.

DE (Direction de l'Elevage), 2005. Rapport annuel (2000 - 2004). Ministère de l'Agriculture de l'Elevage et de la Pêche. Cotonou-Bénin.

Diener S, Lalander C, Zurbrugg C, Vinnerås B. 2015. Opportunities and constraints for medium scale organic waste treatment with fly larvae composting. In: Proceedings of the 15 th International waste management and landfill symposium, Cagliari, Sardinia, 5-9 Oct 2015
Diener S, Studt Solano NM, Roa Gutiérrez F, Zurbrügg C, Tockner K. 2011. Biological Treatment of Municipal Organic Waste using Black Soldier Fly Larvae. Waste and Biomass Valorization, (2): 357-363. DOI: http://dx.doi.org/10.1007/s12649-0119079-1.

Djissou ASM, Tossavi EC, Vodounnou JV, Toguyeni A, Fiogbe ED. 2015. Valorization of agro-alimentary waste for a production of maggots like source of proteins in the animal feeds. International Journal of Agronomy and Agricultural Research, 7(6): 42-46.

FAO. 2015. Secteur Avicole Bénin. Revues Nationales de l'Elevage de la Division de la Production et de la Santé Animales de la FAO, $\mathrm{N}^{\circ} 10$.

Hodomihou RN, Agbossou EK, Amadji GL, Nacrao HB. 2011. Effets de différentes doses de phosphate naturel sur la réduction de la toxicité ferreuse des sols du bas-fond de Niaouli au sud Benin. International Journal of Biological and Chemical Sciences, 5(6): 2278-2290. DOI: http://dx.doi.org/10.4314/ijbcs. v5i6.9.

Hwangbo J, Hong EC, Jang A, Kang HK, Oh JS, Kim BW, Park BS. 2009. Utilization of house fly-maggots, a feed supplement in production of broiler chickens. Journal of Environmental Biology, 30(4): 609-614.

Igue AM, Saidou A, Adjanohoun A, Ezui G, Attiogbe P, Kpagin G, GotoechanHodonou H, Youl S, Pare T, Balogoun I, Ouedraogo J, Dossa E, Mando A, Sogbedji JM. 2013. Evaluation de la fertilité des sols au Sud et au centre du Bénin. Bulletin de la Recherche Agronomique du Bénin., Spécial numéro Fertilisation du maïs : 12-23.

Igué AM. 2009. Impact of Land Use on Chemical and Physical Soil Characteristics in Collines, Benin. Advances in GeoEcology, 40: 72-80.

Karim IYA, Tougan UP, Ahounou SG, Houessionon BFJ, Koutinhouin B. 2013. 
Typology of local poultry breeding of Gallus gallus species in family poultry in Benin. International Journal of Agronomy and Agricultural Research, 3(4): 1-13. DOI: http://dx.doi.org/ 10.6084/M9.FIGSHARE. 1457778.

Kenis M, Koné N, Chrysostome CAAM, Devic E, Koko GKD, Clottey VA, Nacambo S, Mensah GA. 2014. Insects used for animal feed in West Africa. Entomologia, 2:107-114. DOI: http://dx.doi.org/10.4081/entomologia.20 14.218.

Koné NG, Sylla M, Nacambo S, Kenis M. 2017. Production of house fly larvae for animal feed through natural oviposition. J Insects Food Feed., 3(3): 177-186 DOI: http://dx.doi.org/10.3920/ JIFF2016.0044.

Larney FJ, Hao X. 2007. A review of composting as a management alternative for beef cattle feedlot manure in southern Alberta, Canada. Bioresource Technology, 98: 3221-3227. DOI: http://dx.doi.org/10.1016/j.biortech.2006 .07 .005 .

Mpoame M, Téguia A, Nguemfo EL. 2004. Essai comparé de production d'asticots dans les fientes de poule et dans la bouse de vache. Tropicultura., 22(2): 84-87.

Myers HM, Tomberlin JK, Lambert BD, Kattes D. 2008. Development of Black Soldier Fly (Diptera: Stratiomyidae) Larvae Fed Dairy Manure. Environmental Entomology, 37(1): 1115. DOI: http://dx.doi.org/10.1093/ee/ 37.1.11.

Pastor B, Velasquez Y, Gobbi P, Rojo S. 2015. Conversion of organic wastes into fly larval biomass: bottlenecks and challenges. J. Insects Food, 1: 179-193. DOI:

http://dx.doi.org/10.3920/JIFF2014.0024

Pomalégni SCB, Gbemavo DSJC, Kpadé CP, Babatoundé S, Chrysostome CAAM, Koudandé OD, Kenis M, Glèlé Kakaï RL, Mensah GA. 2016. Perceptions et facteurs déterminant l'utilisation des asticots dans l'alimentation des poulets locaux (Gallus gallus) au Bénin. Journal of Applied Biosciences, 98: 9330-9343. DOI: http://dx.doi.org/10.4314/jab.v98i1.9

Pomalégni SCB, Gbemavo DSJC, Kpadé CP, Kenis M, Mensah GA. 2017. Traditional use of fly larvae by small poultry farmers in Benin. Journal of Insects as Food and Feed, 3: 187-192. DOI: https://doi.org/10.3920/JIFF2016.0061.

Saïdou A, Janssen B, Temminghoff EJM. 2003. Effects of soil properties, mulch and NPK fertiliser on maize yields and nutrient budgets on ferralitic soils in southern Benin. Agriculture, Ecosystems and Environment, 100: 265 - 273. DOI: http://dx.doi.org/10.1016/S01678809(03)00184-1.

Saïdou A, Kossou D, Brussaard L, Richards P, Kuyper TW. 2008. Earthworm activities in cassava and egusi melon fields in the transitional zone of Benin: linking farmers' perceptions with field studies. NJAS - Wageningen Journal of Life Sciences, 56-1/2 : 123-135. DOI: http://dx.doi.org/10.1016/S15735214(08)80020-6.

Saïdou A, Kossou DK., Acakpo C, Richards P, Kuyper TW. 2012. Effects of farmers practices of fertilizer application and land use types on subsequent maize yield and nutrient uptake in central Benin. International Journal of Biological and Chemical Sciences, 6(1): 365-378. DOI: http://dx.doi.org/10.4314/ijbcs.v6i1.32.

Sanchez-Arroyo H, Capinera J. 2008. House fly-Musca domestica L. Entomology \& Nematology, Available on http://entnemdept.ufl.edu/creatures/urban /flies/house_fly.htm

Sheppard DC, Newton GL. 2011. Insect Digestion of Manure. An Excerpt from "Manure Management Strategies/Technologies White Paper". Available on www.organicvaluerecovery.com, Consulted on the 14/01/2016. 
Sossa-Vihotogbé ANC, Anihouvi BV, Akissoe HN, Amadji GL, Hounhouigan DJ. 2013. Effect of organic and mineral fertilization on proximate composition of three leafy vegetables harvested at different periods. International Journal of Biological and Chemical Sciences, 7(1): 271-286 DOI: http://dx.doi.org/10.4314/ijbcs.v7i1.23.

Tang R, Zhang F, Kone N, Chen J, Zhu F, Han R, Lei C, Kenis M, Huang L, Wang C. 2016. Identification and testing of oviposition attractant chemical compounds for Musca domestica. Scientific Reports, 6: 33017 . DOI: http://dx.doi.org/10.1038/srep33017.

USDA (United States Department of Agriculture). 1998. Keys to Soil Taxonomy $\left(8^{\text {th }}\right.$ edn). Soil Survey Staff, USDA-NRCS: Washington.

Veldkamp T, van Duinkerken G, van Huis A, Lakemond CMM, Ottevanger E, Bosch G, van Boekel MAJS. 2012. Insects as a sustainable feed ingredient in pig and poultry diets - a feasibility study. Wageningen UR Livestock Research. Report $638 ; 62 \mathrm{p}$.
Wang H, Wang S, Li H, Wang B, Zhou Q, Zhang X, Li J, Zhang Z. 2016. Decomposition and humification of dissolved organic matter in swine manure during housefly larvae composting. Waste Management and Research, 34(5): 465-473. DOI: http://dx.doi.org/10.1177/0734242X1663 6675.

Zhang Z, Wang H, Zhu J, Suneethi S, Zheng J. 2012. Swine manure vermicomposting via housefly larvae (Musca domestica): The dynamics of biochemical and microbial features. Bioresource Technology, 118: 563-571. DOI: http://dx.doi.org/10.1016/j.biortech.2012 .05.048.

Zhu F, Yao Y, Wang S, Du R, Wang W, Chen X, Hong C, Qi B, Xue Z, Yang H. 2015. Housefly maggot-treated composting as sustainable option for pig manure management. Waste management, 35: 62-67.

DOI: http://dx.doi.org/10.1016/j.wasman.2014 .10 .005 . 